(c) American Dairy Science Association, 2003.

\title{
Genetic Parameters for Body Condition Score and its Relationship with Type and Production Traits in Swiss Holsteins
}

\author{
H. N. Kadarmideen* and S. Wegmann† \\ *Statistical Animal Genetics Group, Institute of Animal Science, \\ Swiss Federal Institute of Technology, ETH Zentrum, \\ Zurich $\mathrm{CH}$ 8092, Switzerland and \\ †Holstein Association of Switzerland, Grangeneuve, \\ 1725 Posieux, Switzerland
}

\begin{abstract}
The objectives of this study were to estimate the genetic and environmental parameters between body condition score (BCS) and 27 conformation and 3 production traits in Swiss Holstein cattle. The dataset consisted of 31,500 first-lactation cows, which were daughters of 545 sires in 1867 herds. Bivariate sire models with relationships among sires were used to estimate parameters. Least squares means for BCS by lactation stage show that cows lose BCS up to 5 mo after calving and gain BCS prior to the next calving. Regression models showed that an increase in age and percentage of Holstein genes results in an increase and decrease in BCS, respectively. Heritability $\left(h^{2}\right)$ was 0.24 for BCS score, which indicates good potential for selection. Sire estimated breeding values for BCS ranged from -0.46 to +0.51 units. Heritabilities ranged from 0.08 (heel depth) to 0.46 (rump width) for type traits and 0.23 to 0.29 for yield traits. Genetic correlations of BCS with 8 conformation traits were significant; stature (0.28), heart girth (0.21), strength (0.17), loin (-0.39), body capacity (0.19), dairy character $(-0.35)$, udder quality $(-0.42)$, and teat position rear $(-0.33)$. Milk production and body condition have an unfavorable genetic correlation $(-0.12$ to -0.17$)$. These results show that selection for good body condition, body conformation, and optimal milk production is possible and their genetic associations reported here will be useful for designing Swiss breeding goals.
\end{abstract}

(Key words: body condition score, body type, genetic analysis, milk production)

\section{INTRODUCTION}

Body condition score is a management tool used routinely to assess the body fat reserves and energy status

Received June 8, 2003.

Accepted August 4, 2003.

Corresponding author: H. Kadarmideen; e-mail: haja.

kadarmideen@inw.agrl.ethz.ch. in cattle (Edmonson et al., 1989). Change in BCS over time reflects both body composition and energy balance, which in turn are critical for metabolic stability (Coffey et al., 2001), health (Collard et al., 2000), and fertility (Butler and Smith, 1989; Veerkamp et al., 2001). Many countries have been recording BCS as part of a linear-type classification scheme for several years, and genetic parameters have been estimated (Domecq et al., 1997; Veerkamp and Brotherstone, 1997). Some studies have shown that BCS can be used in selecting robust and profitable animals due to its moderate genetic relationship with other functional traits, such as BW and feed efficiency (Veerkamp and Brotherstone 1997; Coffey et al., 2001; Berry et al., 2002), type traits (Veerkamp and Brotherstone 1997), energy balance, or metabolic stability (Heuer et al., 1999; Coffey et al., 2001) and fertility (Pryce et al., 2001; Dechow et al., 2002, 2003).

Dairy cow fertility is an economically important trait, but heritability is typically low, around 0.03 , and many countries have data quality problems (Kadarmideen et al., 2000, 2003; Kadarmideen and Coffey 2001; Kadarmideen 2003). Body condition score is easily and cheaply recorded as a part of type classification, has a heritability similar to milk yield (range 0.25 to 0.35 ), and has a favorable genetic/phenotypic correlation with fertility traits (Veerkamp et al., 2001; Dechow et al., 2002; Lopez-Gatius et al., 2003). It may also be possible to use BCS as an indicator trait for (metabolic) diseases and disorders because BCS is strongly related to energy balance and longevity (Coffey et al., 2001).

In Switzerland, the Holstein Association started recording BCS in 2001, and these data have never been analyzed. Heritabilities for some type traits in Swiss Holsteins have been estimated, but their genetic/phenotypic correlations with BCS have never been investigated. Very few international studies have reported genetic correlation of BCS with as many conformation and production traits as are considered here. It is of interest to Holstein and other cattle-breeding associa- 
Table 1. Phenotypic means, SD, and heritabilities $\left(\mathrm{h}^{2}\right)$ with their SE for BCS, type, and production traits.

\begin{tabular}{|c|c|c|c|c|c|c|}
\hline \multirow{2}{*}{$\frac{\text { Trait }^{1}}{\text { BCS }}$} & \multicolumn{2}{|c|}{ Range $^{2}$} & \multirow{2}{*}{$\begin{array}{r}\text { Mean } \\
2.74\end{array}$} & \multirow{2}{*}{$\frac{\mathrm{SD}}{0.35}$} & \multirow{2}{*}{$\frac{\mathrm{h}^{2}}{0.24}$} & \multirow{2}{*}{$\begin{array}{l}\text { s.e. } \\
0.03\end{array}$} \\
\hline & Thin & Fat & & & & \\
\hline Stature & Short, $\mathrm{cm}$ & Tall, cm & 143.74 & 6.46 & 0.36 & 0.02 \\
\hline Heart girth & Narrow, cm & Wide, $\mathrm{cm}$ & 193.81 & 9.05 & 0.22 & 0.03 \\
\hline Chest width & Narrow & Wide & 5.09 & 1.21 & 0.27 & 0.03 \\
\hline Body depth & Shallow & Deep & 5.88 & 0.92 & 0.30 & 0.03 \\
\hline Loin & Week & Strong & 5.75 & 0.96 & 0.24 & 0.03 \\
\hline Rump angle & High pins & Low pins & 4.58 & 1.00 & 0.33 & 0.03 \\
\hline Rump width & Narrow & Wide & 6.06 & 1.21 & 0.46 & 0.04 \\
\hline Dairy character & Coarse & Dairy & 5.66 & 0.77 & 0.22 & 0.01 \\
\hline Rear leg side view & Straight & Sickled & 5.73 & 0.74 & 0.14 & 0.02 \\
\hline Pastern & Weak & Strong & 4.51 & 0.80 & 0.18 & 0.02 \\
\hline Heel depth & Low & High heel & 5.08 & 0.77 & 0.08 & 0.01 \\
\hline Rear leg rear view & Toe out & No toe out & 5.24 & 1.03 & 0.16 & 0.02 \\
\hline Fore udder attach & Loose & Tight & 5.54 & 1.15 & 0.14 & 0.02 \\
\hline Rear udder height & Low & High & 5.01 & 1.25 & 0.25 & 0.03 \\
\hline Rear udder width & Narrow & Wide & 5.39 & 1.00 & 0.23 & 0.03 \\
\hline Udder cleft & Weak cleft & Strong cleft & 5.78 & 0.99 & 0.18 & 0.02 \\
\hline Udder depth & Deep & Shallow & 5.41 & 1.21 & 0.30 & 0.03 \\
\hline Udder quality & Fleshy & Soft & 5.66 & 0.94 & 0.26 & 0.03 \\
\hline Teat length & Short & Long & 4.77 & 0.94 & 0.35 & 0.03 \\
\hline Teat position, front & Wide & Close & 4.62 & 1.05 & 0.34 & 0.03 \\
\hline Teat position, rear & Wide & Close & 6.31 & 0.95 & 0.27 & 0.03 \\
\hline Capacity & 50 & 100 & 78.28 & 4.60 & 0.44 & 0.04 \\
\hline Rump & 50 & 100 & 79.86 & 3.74 & 0.21 & 0.03 \\
\hline Dairy & 50 & 100 & 79.83 & 2.43 & 0.25 & 0.03 \\
\hline Feet and legs & 50 & 100 & 79.31 & 2.69 & 0.12 & 0.02 \\
\hline Udder & 50 & 100 & 79.29 & 2.63 & 0.16 & 0.02 \\
\hline Final class & 50 & 85 & 79.08 & 1.98 & 0.22 & 0.03 \\
\hline Milk yield, kg & $\ldots$ & $\ldots$ & 6679 & 1384 & 0.29 & 0.03 \\
\hline Fat yield, $\mathrm{kg}$ & $\ldots$ & $\ldots$ & 259 & 54 & 0.23 & 0.03 \\
\hline Protein yield, kg & $\ldots$ & $\ldots$ & 245 & 61 & 0.29 & 0.03 \\
\hline
\end{tabular}

${ }^{1}$ Capacity consists of stature, heart girth, strength, body depth and loin; rump includes rump angle and rump width; dairy include dairy character, udder texture and bone quality; feet and legs include rear leg rear view, rear leg side view, pastern and heel depth; teat position traits are the relative position of teats (front and rear) under the quarters.

${ }^{2}$ Body condition scores and type traits were recorded on 1 to 5 and 1 to 9 scales, respectively.

tions of Switzerland (Brown Swiss and Simmental) to estimate genetic and phenotypic parameters of BCS data collected up to this point and to investigate the genetic and other relationships of BCS with production and type traits that are in the national economic selection index. Therefore, the main objectives of this study were to estimate genetic and phenotypic parameters of BCS and its genetic and phenotypic correlation with type and milk production traits.

\section{MATERIALS AND METHODS}

\section{Data}

Body condition scores have been routinely recorded since 2001 by Holstein Association of Switzerland as a part of the linear-type classification program. Body condition score is recorded on 1 to 5 scale $(1=$ very thin, 5 = very fat) with an increment of 0.25 , type traits are recorded on 1 to 9 scale or in centimeters. Descriptive type traits are recorded on a 50 to 100 point scale, but the maximum score given to the "final class" of first-lactation cows is 85 points (Table 1 ).
Body condition score data on first-lactation cows from 2 yr (2001 and 2002) were used in this study. Data on all 27 linear type traits and 3 milk production traits were also obtained for cows with a BCS record. We included 2 other (previous) years of data on type and production, starting arbitrarily from year 1999, to improve the accuracy of bivariate analysis of BCS with type or production traits. Data were edited such that each sire had at least 10 daughters and each herd had at least 10 lactation and type records across all years, which resulted in a final dataset of 31,500 records. All records had production and conformation data, and 13,931 of 31,500 records had BCS data. Fixed effects used in statistical analysis included 6815 herd-year of calving classes, 6229 herd-year of visits by classifier, 12 classes for month of calving effect or classification, and 9 classes for stage of lactation effects. A sire model with relationships among sires was used in constructing A matrix for mixed-model analysis. Pedigrees were traced as far back as possible and included 857 sires. 


\section{Statistical Models and Analyses}

Estimation of genetic and environmental parameters was performed by two-trait analysis using one type or milk production trait along with BCS. The bivariate model was:

$$
\left[\begin{array}{l}
\mathbf{y}_{1} \\
\mathbf{y}_{2}
\end{array}\right]=\left[\begin{array}{cc}
\mathbf{X}_{1} & 0 \\
0 & \mathbf{X}_{2}
\end{array}\right]\left[\begin{array}{l}
\mathbf{b}_{1} \\
\mathbf{b}_{2}
\end{array}\right]+\left[\begin{array}{cc}
\mathbf{z}_{1} & 0 \\
0 & \mathbf{Z}_{2}
\end{array}\right]\left[\begin{array}{l}
\mathbf{s}_{1} \\
\mathbf{s}_{2}
\end{array}\right]+\left[\begin{array}{l}
\mathbf{e}_{1} \\
\mathbf{e}_{2}
\end{array}\right]
$$

where $\mathbf{y}_{1}$ was a vector of records of type or milk production traits and $\mathbf{y}_{2}$ was a vector of BCS records, respectively; $\mathbf{X}_{1}$ and $\mathbf{X}_{2}$ were design matrices relating fixed effects in $\mathbf{b}_{1}$ and $\mathbf{b}_{\mathbf{2}}$ to $\mathbf{y}_{\mathbf{1}}$ and $\mathbf{y}_{2}$, respectively. The fixed effects in the model for milk production $\left(\mathbf{b}_{1}\right)$ and BCS $\left(\mathbf{b}_{2}\right)$ were:

$$
\mathbf{b}_{1}=\left[\begin{array}{c}
\mu \\
\text { HYC } \\
\text { MC } \\
\text { ac } \\
\text { hp }
\end{array}\right] \text {, and } \mathbf{b}_{2}=\left[\begin{array}{c}
\mu \\
\text { HYV } \\
\mathbf{L S} \\
\text { MT } \\
\text { at } \\
\text { hp }
\end{array}\right]
$$

and the fixed effects for the conformation traits were the same as those used for BCS $\left(\mathbf{b}_{2}\right)$, where $\mu=$ the overall mean, $H Y C=$ herd-year of calving, $M C=$ month of calving, $a c=$ age (in days) at calving as a covariate, $H Y V=$ herd-year of visit by classifier, $L S=$ stage of lactation (in months) at the time of classification, $M T$ $=$ month of type classification, $a t=$ age (in days) at condition scoring or type classification as a covariate, and $h p=$ percentage of Holstein genes as a covariate.

The vector of random effects of sire was included in $\mathbf{s}_{\mathbf{1}}$ and $\mathbf{s}_{\mathbf{2}}$, where the design matrices, $\mathbf{Z}_{\mathbf{1}}$ and $\mathbf{Z}_{2}$, relate records to these sire effects. The vector of random residuals were $\mathbf{e}_{\mathbf{1}}$ and $\mathbf{e}_{2}$ for $\mathbf{y}_{\mathbf{1}}$ and $\mathbf{y}_{2}$, respectively. The expectation $(\mathbf{E})$ and variances $(\mathbf{V})$ of model terms were as follows:

$$
\begin{gathered}
\mathbf{E}\left[\begin{array}{l}
\mathbf{y}_{1} \\
\mathbf{y}_{2}
\end{array}\right]=\left[\begin{array}{cc}
\mathbf{X}_{1} & 0 \\
0 & \mathbf{X}_{2}
\end{array}\right]\left[\begin{array}{l}
\mathbf{b}_{1} \\
\mathbf{b}_{2}
\end{array}\right]=\left[\begin{array}{l}
\mathbf{X}_{1} \mathbf{b}_{1} \\
\mathbf{X}_{2} \mathbf{b}_{2}
\end{array}\right] \text { and } \\
\mathbf{V}\left[\begin{array}{l}
y_{1} \\
y_{2}
\end{array}\right]=\mathbf{V}\left[\begin{array}{ll}
\mathbf{Z}_{1} \mathbf{s}_{1}+\mathbf{e}_{1} \\
\mathbf{Z}_{2} \mathbf{S}_{2}+\mathbf{e}_{2}
\end{array}\right]=\left[\begin{array}{cc}
\mathbf{Z}_{1} & \mathbf{0} \\
\mathbf{0} & \mathbf{Z}_{2}
\end{array}\right] \mathbf{G}\left[\begin{array}{cc}
\mathbf{Z}_{1}^{\prime} & \mathbf{0} \\
\mathbf{0} & \mathbf{Z}_{2}^{\prime}
\end{array}\right]+\mathbf{R}
\end{gathered}
$$

where

$$
\begin{gathered}
\mathbf{G}=\mathbf{G}_{0} \otimes \mathbf{A}, \\
\mathbf{G}_{0}=\left[\begin{array}{cc}
\sigma_{s_{1}}^{2} & \sigma_{s_{12}}^{2} \\
\sigma_{s_{21}}^{2} & \sigma_{s_{2}}^{2}
\end{array}\right],
\end{gathered}
$$

and where $\mathbf{A}$ is the additive relationship matrix and $\otimes$ is the Kronecker product. Also, $\mathbf{R}$ is residual variancecovariance matrix with

$$
\mathbf{R}=\mathbf{R}_{\mathbf{0}} \otimes \mathbf{I},
$$

where,

$$
\mathbf{R}_{\mathbf{0}}=\left[\begin{array}{cc}
\sigma_{e_{1}}^{2} & \sigma_{e_{12}} \\
\sigma_{e_{21}} & \sigma_{e_{2}}^{2}
\end{array}\right]
$$

and $\mathbf{I}$ is the identity matrix. Each trait was assumed to follow multivariate normal distributions with the above mean and variance-covariances. We assumed no covariance between residuals and genetic effects; cov $(\mathbf{s}, \mathbf{e})=0$. It should be noted that BCS data is missing on some animals; therefore, the residual elements corresponding to rows and columns of animals that has missing BCS observations in $\mathbf{R}_{\mathbf{0}}$ are set to zero. Handling of missing observations for one or more traits in multi-trait mixed model equations are described by Henderson (1984).

Data were also analyzed by univariate models, which consisted of the same effects as those fitted for individual traits in bivariate settings (in $\mathbf{b}_{\mathbf{1}}$ and $\mathbf{s}$ for production traits and $\mathbf{b}_{2}$ and $\mathbf{s}$ for BCS and type traits). Univariate results were used for obtaining starting values for variance components estimation by the bivariate models, for estimating least squares means for fixed effects of BCS and to examine the distribution of BCS EBV.

Implementation and software. Variance-covariance parameters for all models were estimated using the software package, ASREML (Gilmour et al., 2001). Heritabilities $\left(h^{2}\right)$ and all correlations (genetic- $r_{g}$, residual- $r_{e}$, and phenotypic- $r_{p}$ ) were computed using estimated variance-covariance matrices. In ASREML, it was possible to get standard errors for all estimated parameters or its ratios. In total, there were 61 blocks of genetic analyses ( 31 for univariate and 30 for bivariate analyses). It was not our aim to compute correlations (covariances) among type traits or between type and milk production traits.

\section{RESULTS}

\section{Descriptive Statistics}

Phenotypic means and standard deviations of BCS, type, and milk production traits are given in Table 1 along with their heritability estimates. Mean (SD) of BCS was 2.74 (0.35) and a coefficient of variation was 


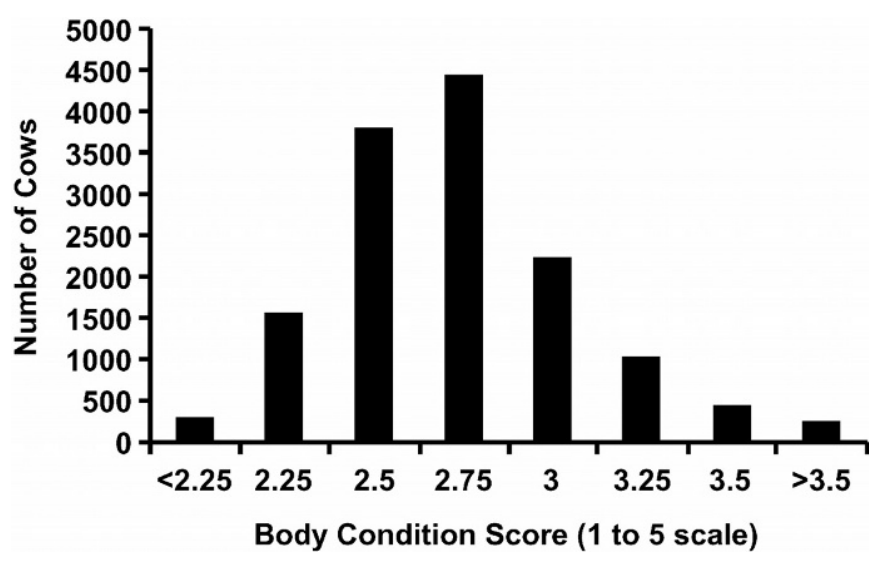

Figure 1. Distribution for BCS.

13\%. The distribution of BCS is plotted in Figure 1, which shows that a BCS of 2.75 was more frequent, followed by $2.5,3.0,2.25$, and 3.25. Scores less than 2.25 or greater than 3.5 were rare. The mean and variance observed for BCS are similar to those observed in most other countries (Pryce et al., 2001; Berry et al., 2002), where BCS are measured on a 1 to 5 scale. Means for all type traits, scored on 1 to 9 scale, were in the range of 4.51 for pastern to 6.31 for teat position rear with SD in the range of 0.74 to 1.25. Composite type traits (capacity, rump, dairy, feet and legs, udder, and final class) had a mean of 79.0, with SD ranging from 1.98 to 4.60 . Means and SD for milk production traits were as expected for Swiss Holstein populations. Mean and SD for age at classification were 1019 and $130 \mathrm{~d}$, respectively, and for Holstein genes was 95.1 and $8.2 \%$, respectively. The range of Holstein genes percentages was 44 to $100 \%$.

\section{Fixed Effects for BCS}

Age and Holstein genes. Estimated regression coefficient of BCS on age at classification, derived from univariate analysis of BCS, was 0.002 , and on percentage of Holstein genes was -0.003 . This indicates that for every day increase in age at classification, BCS increases, on average, 0.002 units (or for a 1-mo increase in age: $0.002 \times 30=0.06 \mathrm{BCS}$ units). A $1 \%$ increase in Holstein genes decreases BCS by 0.003 units. Regression coefficients of age and Holstein genes were significant at the $P<0.05$ level.

Lactation stage and month of classification. Least squares means for the month of classification and stage of lactation, derived from univariate analysis of BCS, are given in Table 2. Least squares means of BCS for month of classification effect (significant at $P<0.05$ for all levels except the month of July) indi- cated that cows that were classified in January or February tended to have, on average, smaller scores than those condition scored in December. Raw means computed from the data showed May and August had lowest and highest scores, respectively.

Least squares means for stage of lactation effect with levels 1 to 9 are also given in Table 2. Here, lactation stage 1 is for cows that were condition scored at calving or between 0 and $30 \mathrm{~d}$ postcalving, and levels 2 to 9 correspond to cows that were condition scored between 1 and 9 mo after calving. Least squares means were significant at $P<0.01$ for all levels. Results in Table 2 indicate that at the time of calving, cows started with good body condition, progressively lost condition (mobilized body reserves of fat) for up to 4 or 5 mo after calving, and then started to gain body reserves of fat for the next calving. Raw means for stage of lactation effect also showed similar trends, but the magnitude was approximately $0.20 \mathrm{BCS}$ units less than for LS means.

The BCS loss or gain can be better visualized in weeks rather than months because some of the BCS changes during a crucial part of lactation seem to happen in a matter of weeks. Figure 2 shows that the mean BCS by stage of lactation (in weeks) from calving date. There were only 7 cows classified in wk 1, but a reasonable number of cows was classified in later weeks (98 in wk 2, 284 in wk 3, 386 in wk 4, etc.). As seen in Figure 2, the drop in body condition was fast in the first $12 \mathrm{wk}$, moderate for the following $10 \mathrm{wk}$, and then cows seemed to put on fat reserves after 22 wk. Similar phenotypic trends (in months or weeks) have been observed in earlier studies (Jones et al., 1999; Pryce et al., 2001; Berry et al., 2002).

\section{Heritabilities}

Heritabilities $\left(\mathrm{h}^{2}\right)$ estimated from bivariate analyses of all traits (with BCS) are given in Table 1, along with their standard errors. Heritability for BCS was 0.24 . There were 30 different estimates of heritability for BCS from bivariate analyses and they varied between 0.23 and 0.25. Among type traits, heel depth had the lowest heritability (0.08), and rump width had the highest heritability (0.46). The range of estimated heritability was 0.14 to 0.30 for udder traits, 0.08 to 0.18 for "feet and leg" traits, and 0.21 to 0.46 for "rump" traits. The heritability estimates were significant for all 27 type traits and BCS, with standard error being less than 0.05 . For milk production traits, estimates of heritability were 0.29 for milk and protein yield, and 0.23 for fat yield. 
Table 2. Least squares means and raw means for calendar month classification and stage of lactation (in months) for Body Condition Scores of first lactation cows.

\begin{tabular}{|c|c|c|c|c|c|}
\hline \multicolumn{3}{|c|}{ Month of classification ${ }^{1}$} & \multicolumn{3}{|c|}{ Stage of lactation ${ }^{2}$} \\
\hline $\begin{array}{l}\text { Calendar } \\
\text { month }\end{array}$ & $\begin{array}{l}\text { Least } \\
\text { squares } \\
\text { means }\end{array}$ & $\begin{array}{l}\text { Raw } \\
\text { means }\end{array}$ & $\begin{array}{l}\text { Lactation } \\
\text { stage } \\
\text { in month }\end{array}$ & $\begin{array}{l}\mathrm{LS} \\
\text { means }\end{array}$ & $\begin{array}{l}\text { Raw } \\
\text { means }\end{array}$ \\
\hline 1 & 2.33 & 2.73 & $0-1$ & 3.00 & 2.93 \\
\hline 2 & 2.33 & 2.65 & $1-2$ & 2.98 & 2.81 \\
\hline 3 & 2.34 & 2.64 & $2-3$ & 2.93 & 2.71 \\
\hline 4 & 2.35 & 2.67 & $3-4$ & 2.93 & 2.70 \\
\hline 5 & 2.36 & 2.63 & $4-5$ & 2.92 & 2.67 \\
\hline 6 & 2.41 & 2.70 & $5-6$ & 2.92 & 2.69 \\
\hline 7 & 2.34 & 2.75 & $6-7$ & 2.94 & 2.73 \\
\hline 8 & 2.40 & 2.91 & $7-8$ & 2.95 & 2.75 \\
\hline 9 & 2.38 & 2.81 & $8-9$ & 2.99 & 2.77 \\
\hline 10 & 2.40 & 2.71 & & & \\
\hline 11 & 2.41 & 2.77 & & & \\
\hline 12 & 2.47 & 2.71 & & & \\
\hline
\end{tabular}

${ }^{1}$ Standard error of least squares means was 0.236 for all levels, and ranged from 0.01 to 0.04 for raw means.

${ }^{2}$ Standard error of least squares means was 0.22 for all stages, and ranged from 0.01 to 0.32 for raw means.

\section{Sire EBV for BCS}

The distribution of BCS EBV for 857 sires (in the pedigree) is plotted in Figure 3. The minimum and maximum of sire EBV were -0.46 and +0.51 , respectively (Figure 3). The standard deviation of EBV was 0.09 , and about $95 \%$ of the bulls EBV ranged between -2 to +2 standard deviation units. This can be seen in Figure 3, where there is a higher peak at the center of the distribution (Figure 3) compared with the normal distribution. When distribution of EBV was tested for deviation from normality, there was a positive kurtosis of 2.75, showing that most sires' EBV were in fact very close to the mean. Although, there is not much ideal spread of BCS EBV among sires, the estimated heritability of 0.24 (Table 2) would help in distinguishing worst/best sires for daughters' BCS, and thus help in selection and breeding.

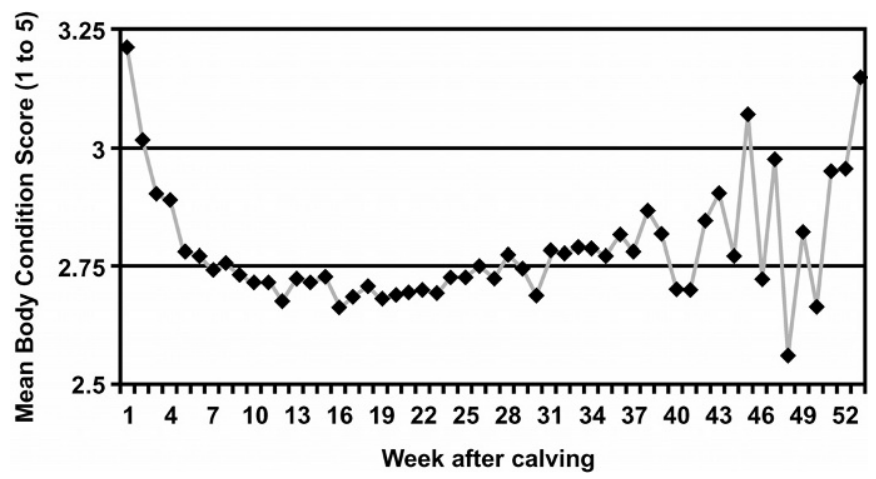

Figure 2. Distribution of mean BCS over weeks after calving.

\section{Body Condition Score and Type Traits}

Estimates of genetic correlations of BCS with type traits (with SE) are given in Table 3 along with residual and phenotypic correlations. Estimates of genetic correlations were significantly different from zero for stature, heart girth, strength, loin, dairy character, udder quality, teat position rear, and capacity. Body condition score had a moderately positive ( 0.17 to 0.28$)$ genetic correlation with stature, heart girth, strength, and capacity. Moderately negative $(-0.33$ to -0.42$)$ genetic correlations of BCS were found for loin, dairy character, udder quality, and teat position rear. Some of these genetic and phenotypic correlations may be explained by trait definition or practicality of measurement. Loin, for example, had a genetic correlation of -0.39 with BCS. This may be due to difficulty of scoring

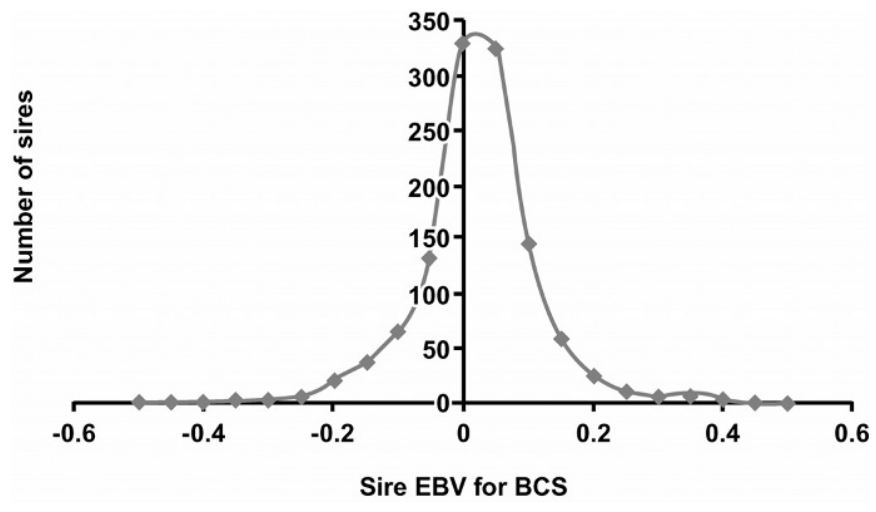

Figure 3. Distribution of BCS EBV among sires, as estimated by univariate sire models. 
Table 3. Genetic, residual, and phenotypic correlations $\left(r_{g}, r_{e}\right.$, and $r_{p}$, respectively) with their SE between BCS and 27 type traits, based on 31,500 records.

\begin{tabular}{lclrlrl}
\hline Trait & $\mathrm{r}_{\mathrm{g}}$ & $\mathrm{r}_{\mathrm{g}}(\mathrm{SE})$ & $\mathrm{r}_{\mathrm{e}}$ & $\mathrm{r}_{\mathrm{e}}(\mathrm{SE})$ & $\mathrm{r}_{\mathrm{p}}$ & $\mathrm{r}_{\mathrm{p}}(\mathrm{SE})$ \\
\hline Stature & $0.28^{1}$ & 0.08 & 0.16 & 0.01 & 0.16 & 0.01 \\
Heart girth & $0.21^{1}$ & 0.08 & 0.17 & 0.01 & 0.17 & 0.01 \\
Strength & $0.17^{1}$ & 0.08 & 0.11 & 0.01 & 0.11 & 0.01 \\
Body depth & -0.05 & 0.11 & 0.07 & 0.01 & 0.06 & 0.01 \\
Loin & $-0.39^{1}$ & 0.08 & -0.27 & 0.01 & -0.28 & 0.01 \\
Rump angle & 0.06 & 0.11 & 0.01 & 0.01 & 0.02 & 0.01 \\
Rump width & -0.07 & 0.11 & -0.04 & 0.01 & -0.04 & 0.01 \\
Dairy character & $-0.35^{1}$ & 0.07 & -0.11 & 0.01 & -0.13 & 0.01 \\
Rear leg side view & -0.18 & 0.12 & -0.08 & 0.01 & -0.09 & 0.01 \\
Pastern & -0.03 & 0.11 & 0.01 & 0.01 & 0.01 & 0.01 \\
Heel depth & 0.14 & 0.09 & 0.10 & 0.01 & 0.10 & 0.01 \\
Rear leg rear view & 0.14 & 0.11 & 0.09 & 0.01 & 0.09 & 0.01 \\
Fore udder attach & -0.18 & 0.12 & -0.09 & 0.01 & -0.09 & 0.01 \\
Rear udder height & -0.14 & 0.11 & -0.02 & 0.01 & -0.02 & 0.01 \\
Rear udder width & -0.16 & 0.11 & 0.01 & 0.01 & -0.00 & 0.01 \\
Udder cleft & -0.11 & 0.11 & -0.08 & 0.01 & -0.08 & 0.01 \\
Udder depth & 0.09 & 0.11 & 0.01 & 0.01 & 0.01 & 0.01 \\
Udder quality & $-0.42^{1}$ & 0.09 & -0.17 & 0.01 & -0.18 & 0.01 \\
Teat length & -0.07 & 0.10 & 0.03 & 0.01 & 0.02 & 0.01 \\
Teat position front & -0.08 & 0.10 & -0.01 & 0.01 & -0.02 & \\
Teat position rear & $-0.33^{1}$ & 0.09 & -0.07 & 0.01 & -0.09 & 0.01 \\
Capacity & $0.19^{1}$ & 0.06 & 0.11 & 0.01 & 0.11 & 0.01 \\
Rump & 0.06 & 0.08 & 0.03 & 0.01 & 0.03 & 0.01 \\
Dairy & 0.03 & 0.05 & -0.01 & 0.01 & -0.02 & 0.01 \\
Feet and legs & 0.15 & 0.08 & 0.06 & 0.04 & 0.07 & 0.01 \\
Udder & 0.04 & 0.08 & -0.02 & 0.02 & -0.01 & 0.01 \\
Final class & 0.13 & 0.07 & 0.07 & 0.03 & 0.07 & 0.01 \\
\hline
\end{tabular}

${ }^{1} r_{g}$ estimate significantly different from zero.

loin as "strong" on fat cows, whereas a "strong" loin can be seen easily on thin cows. The direction and magnitude of the genetic correlation mostly agrees with our expectation. For example, high BCS and stature or heart girth are positively associated or thin cows (with low BCS) tend to have been scored high for dairy form and hence negatively associated. Dairy character could be considered an indicator of functional traits, such as fertility and health, since this trait also indicates relative fatness of dairy cows, similar to BCS. In fact, dairy form has a genetic correlation of -0.73 with BCS (Dechow et al., 2003). In general, observed genetic correlations could be pleiotropic effects of genes influencing BCS, and these type traits could also be a result of generations of selection based on certain combinations of type characteristics, which in turn may have resulted in some gene combinations, not necessarily pleiotrophic, but in a linkage disequilibrium. Generally, estimates of genetic correlations between BCS and type traits were favorable, suggesting that selection for good BCS would increase the chances of having genetic merit for desired type.

Estimates of residual correlations and phenotypic correlations are also given in Table 3 . In general, estimates of residual correlations were lower than estimates of genetic correlations. Absolute estimates of residual correlations between BCS and type traits were generally low. In general, the direction and magnitude of estimates of phenotypic correlations were similar to estimates of residual correlations. Estimates of phenotypic correlations between BCS and type traits were low and mostly negative, except for stature, heart girth, strength, heel depth, and capacity. Estimates of phenotypic correlations with type traits ranged from -0.28 for loin to +0.16 for stature.

\section{Body Condition Score and Milk Production Traits}

Genetic correlations of BCS with milk production traits (with SE) are given in Table 4 . They were -0.12 for both milk and protein yield and -0.17 for fat yield. Estimates for milk and protein yield were not highly significant. However, these results indicate that increased genetic merit for milk, fat, and protein yield would result in decreased genetic merit for BCS in the long-term selection. Estimates of residual and phenotypic correlations are also given in Table 4. Estimates of residual correlations were lower than estimates of genetic correlations (around 0.03) and negative. Estimate of phenotypic correlation between BCS and milk yield showed that increased milk yield, fat, and protein yield are associated with lower BCS. The standard error was 0.01 for all estimates of residual correlations and phenotypic correlations. 
Table 4. Genetic, residual and phenotypic correlations $\left(r_{g}, r_{e}\right.$, and $r_{p}$, respectively) with their SE between BCS and 3 milk production traits, based on 31,500 records.

\begin{tabular}{lllllll}
\hline & $\mathrm{r}_{\mathrm{g}}$ & $\mathrm{r}_{\mathrm{g}}(\mathrm{SE})$ & $\mathrm{r}_{\mathrm{e}}$ & $\mathrm{r}_{\mathrm{e}}(\mathrm{SE})$ & $\mathrm{r}_{\mathrm{p}}$ & $\mathrm{r}_{\mathrm{p}}(\mathrm{SE})$ \\
\hline Milk yield & -0.12 & 0.07 & -0.03 & 0.01 & -0.05 & 0.01 \\
Fat yield & $-0.17^{1}$ & 0.07 & -0.04 & 0.01 & -0.05 & 0.01 \\
Protein yield & -0.12 & 0.07 & -0.04 & 0.01 & -0.04 & 0.01 \\
\hline
\end{tabular}

${ }^{1} r_{g}$ estimate significantly different from zero.

\section{DISCUSSION}

Body condition score has emerged as a possible indicator trait for many functional traits (e.g., energy balance, fertility, metabolic disorders) that are costly and difficult to record because of its genetic association with those functional traits. Evidence in other countries indicates that it can be used to breed for healthy, fertile, and metabolically or energetically stable animals (Heuer et al., 1999; Dechow et al., 2002).

In Switzerland, the Holstein Association started recording BCS as part of the type classification scheme in 2001 . Here, we report estimates of genetic and environmental effects that affect BCS and their association with those of body conformation and milk production traits, using the BCS data collected up to this point. Such genetic parameters (heritabilities and genetic correlations) are needed to construct new or modify existing Swiss selection indexes, which are aimed at selecting "genetically optimal" animals, giving due economic weight to production and type traits. In this study, genetic and phenotypic parameters were estimated for BCS, type, and production traits, for that purpose.

Regression of BCS on Holstein genes showed that an increase in Holstein genetics decreases body condition. This trend has been observed by others (e.g., Veerkamp et al., 2001; Berry et al., 2002). Regression estimates of age at classification showed that BCS increases with age, and many other type traits also changed as a function of age (in days). These results are to be expected, but here we quantified such changes in body composition or type as a function of age.

Least squares means for 9 stages of lactation (Table 2 ) and BCS loss or gain in weeks (Figure 2) indicated that, at the time of calving, cows start with good body condition, lose condition progressively up to approximately 22 wk (about $5 \mathrm{mo}$ ) of calving, and then tend to gain body condition to maintain later stages of pregnancy and calve again. Similar phenotypic trend (in months or weeks) has been observed in earlier studies (Jones et al., 1999; Pryce et al., 2001; Berry et al., 2002). All estimates of fixed effects for BCS reported here were derived from univariate analysis of BCS which when compared to estimates from series of bi- variate analysis of BCS with type or production traits were similar.

Heritability of BCS obtained in this study was 0.24 , which is similar to estimates reported by Pryce et al. (2001), Gallo et al. (2001), and Berry et al. (2002). There were some slight differences between our estimates and estimates of Dechow et al. (2002) and Veerkamp et al. (2001), but these differences may be due to differences in definition of BCS (some studies defined and estimated parameters for BCS as longitudinal measurements or used a different scale of measurements: 1 to 5 vs. 1 to 9 ), sire vs. animal models, standard deviations of the traits analyzed, and different data editing and estimation procedure used.

Estimates of heritability for many type traits are similar to most literature estimates (Rupp and Boichard 1999; Gallo et al., 2001). Heritabilities for type traits reported in this study were, in general, similar to those used in genetic evaluation by the Swiss Holstein Association (S. Wegmann, personal communication).

Direction and magnitude of genetic correlation of BCS with many type traits (e.g., heart girth, rear leg side view, fore udder attachment, udder depth, and teat position rear) found in this study were similar to earlier literature estimates (Veerkamp and Brotherstone 1997; Pryce et al., 2001). Genetic correlations between BCS and 305-d milk production traits were, in general, unfavorable, so a genetic decline in body condition is to be expected if selection for production alone continues in future. Some studies have reported these antagonistic genetic correlations between BCS and yield traits on a more severe scale (Pryce et al. [2001] for the U.K.; Berry et al. [2002] for Ireland; approximately $-0.63,-0.41$, and -0.54 for milk, fat, and protein yield, respectively) or on a moderate scale of approximately -0.20 to -0.30 (Veerkamp et al. [2001] and Dechow et al. [2003] for Dutch and U.S. data, respectively). Our estimates $(-0.12$ to -0.17$)$ are probably underestimated due to having missing BCS observations in bivariate analyses, using sire models instead of animal models or different estimation methods, or a combination of these reasons.

Estimates of genetic and environmental parameters for BCS reported in this study should be validated after collecting more years of BCS data and reanalysis. 
For example, very small differences in LS means for stage of lactation effect (Table 2), narrow distribution of sire BCS EBVs (Figure 3), nonsignificant genetic correlation of milk or protein yield with BCS (Table 4) may change when analyses are repeated with few more years of additional data.

In this study, we considered a single observation of BCS per cow and correspondingly estimated genetic parameters for this cross-sectional data. It is also of interest to know how body condition/composition changes over the trajectory of lactation according to the demands for production and maintenance. In this case, we would have to record BCS at different stages of lactation at the cow level, and it would be almost impossible on a national scale. One approach to collecting these longitudinal data for BCS would be to collect data on daughters of sires, with condition score at different stages of lactation, such that sires' genetic merit is estimated based on their daughters' data sorted by stages of lactation. Random regression models for longitudinal BCS data was first applied by Jones et al. (1999) to U.K. data and later applied by Veerkamp et al. (2001) to Dutch data. As more data accumulate for BCS sufficient for sire by stage of lactation classes, this random regression model would be a preferred approach as this can overcome the problem of limited data at the cow level, as well as improve accuracy of predictions. In future, we plan to apply random regression models to our datasets.

Kadarmideen et al. (2003) showed that single-trait genetic evaluation for fertility will be biased and recommended that fertility breeding values be calculated from a multitrait analysis that includes milk yield as a correlated trait. A similar principle would also be applicable to genetic evaluation for BCS because farmers may select cows for breeding based on their genetic merit for milk yield (in which case, genetically thin animals are preferentially treated). This bivariate analysis of BCS with milk yield needs further investigation. Type traits and longevity have a moderate genetic correlation (Vollema et al., 1997). In our study, we showed that BCS is genetically related to stature, heart girth, capacity, and to overall scores for some conformation traits, such as udder, feet, and legs. This indicates that selection for optimal body condition together with these important conformation traits is likely to increase longevity. The use of BCS as a predictor of longevity, however, depends on how much information BCS provides over and above those found in these conformation traits.

\section{CONCLUSIONS}

Body condition score and its genetic relationship with conformation and milk production traits in first- lactation Swiss Holstein cows was analyzed. Estimated regression coefficients show that an increase in the percentage of Holstein genes results in decrease in BCS. An increase in the percentage of Holstein genes mostly increased the scores for desirable type. Body condition score has moderate heritability $(0.24)$, indicating that this trait is good for selection, similar to milk yield. Body condition score was favorably genetically related to some conformation traits, such as body capacity (0.19), stature (0.28), heart girth (0.21), strength (0.17), and overall scores for feet and legs $(0.15)$ and final class $(0.13)$. Milk production and body condition have an unfavorable genetic correlation $(-0.12$ to -0.17$)$, suggesting that future selection should be aimed at optimal selection for milk yield as well as body condition.

\section{ACKNOWLEDGMENT}

Two anonymous reviewers are thanked for their useful comments on the manuscript.

\section{REFERENCES}

Berry, D. P., F. Buckley, P. Dillion, R. D. Evans, M. Rath, and F. Veerkamp. 2002. Genetic parameters of body condition score and body weight in dairy cows. J. Dairy Sci. 85:2030-2039.

Butler, W. T. and R. D. Smith 1989. Interrelationships between energy balance and postpartum reproductive function in dairy cattle. J. Dairy Sci. 72:767-783.

Coffey, M. P., G. C Emmans, and S. Brotherstone. 2001. Genetic evaluation of dairy bulls for energy balance traits using random regression. Anim. Sci. 73:29-40.

Collard, B. L., P. J. Boettcher, J. C. M. Dekkers, D. Pettitclerc, and L. R. Schaeffer. 2000. Relationship between energy balance and health traits of dairy cattle in early lactation. J. Dairy Sci. 83:2683-2690.

Dechow, C. D., G. W. Rogers, and J. S. Clay. 2002. Heritability and correlations among body condition scores loss, body condition score, production and reproductive performance. J. Dairy Sci. 85:3062-3070.

Dechow, C. D., G. W. Rogers, T. J. Lawlor, L. Klei, and P. M. VanRaden. 2003. Genetic correlation estimates among body condition score, dairy form, days open and production traits for U.S. Holsteins. J. Dairy Sci. 86(Suppl.1):130. (Abstr.)

Domecq, J. J., A. L. Skidmore, J. W. Lloyd, and J. B. Kaneene, 1997. Relationship between body condition scores and conception at first artificial insemination in a large dairy herd of high yielding Holstein cows. J. Dairy Sci. 80:113-120.

Edmondson, A. J., I. J. Lean, L. D. Weaver, T. Farvver, and G. Webster. 1989. A body condition scoring chart for Holstein dairy cows. J. Dairy Sci. 72:68-78.

Gallo, L., P. Carnier, M. Cassandro, R. Dal Zotto, and G. Bittante. 2001. Test-day genetic analysis of condition score and heart girth in Holstein Friesian cows. J. Dairy Sci. 84:2321-2326.

Gilmour, A. R., B. R. Cullis, S. J. Welham, and R. Thompson. 2001. ASREML Reference Manual. New South Wales Agriculture, Orange Agric. Inst., Orange, NSW, Australia.

Henderson, C. R. 1984. Applications of Linear Models in Animal Breeding. Univ. of Guelph, Guelph, Canada.

Heuer, C., Y. H. Schukken, and P. Dobbelaar. 1999. Postpartum body condition score and results from the first test day milk as predictors of disease, fertility, yield and culling in commercial dairy herds. J. Dairy. Sci. 82:295-304. 
Jones, H. E., I. M. S. White, and S. Brotherstone. 1999. Genetic evaluation of Holstein-Friesian sires for daughter conditionscore changes using a random regression model. Anim. Sci. 68:467-475.

Kadarmideen, H. N., R. Thompson, and G. Simm. 2000. Linear and threshold model genetic parameter estimates for disease, fertility and production traits in UK dairy cattle. Anim. Sci. 71: 411-419.

Kadarmideen, H. N., and M. P. Coffey. 2001. Quality and validation of insemination data for national genetic evaluations for dairy cow fertility in the United Kingdom. Pages 133-138 in Interbull Bull. No. 27.

Kadarmideen, H. N. 2003. Recording disease and reproductive events in dairy cattle for developing national health and fertility selection indices. Pages 157-161 in Proc. 33rd Biennial Session of ICAR. EAAP Publication No. 107. Wageningen Academic Publishers, Wageningen, The Netherlands.

Kadarmideen, H. N., R. Thompson, M. P. Coffey, and M. A. Kossaibati. 2003. Genetic parameters and evaluations from single- and multiple- trait analysis of dairy cow fertility and milk production. Livest. Prod. Sci. 81:183-195.
Lopez-Gatius, F., J. Yaniz, and D. Madriles-Helm. 2003. Effects of body condition score and score change on the reproductive performance of dairy cows: A meta-analysis. Theriogenology 59:801-812.

Pryce, J. E., M. P. Coffey, and G. Simm. 2001. The relationship between body condition score and reproductive performance. J. Dairy Sci. 84:1508-1515.

Rupp, R., and D. Boichard. 1999. Genetic parameters for clinical mastitis, somatic cell score, production, udder type traits, and milking ease in first lactation Holsteins. J. Dairy Sci. 82:2198-2204.

Veerkamp, R. F., and S. Brotherstone. 1997. Genetic correlations between linear type traits, food intake, live weight and condition score in Holstein Friesian dairy cattle. Anim. Sci. 64:385-392.

Veerkamp., R. F., E. P. C. Koenen., and G. De Jong. 2001. Genetic correlations among body condition score, yield, and fertility in first-parity cows estimated by random regression models. J. Dairy Sci. 84:2327-2335.

Vollema, A. R., and A. F. Groen. 1997. Genetic correlations between longevity and conformation traits in an upgrading dairy cattle population. J. Dairy Sci. 80:3006-3014. 